\title{
Changes in production and respiration during a spring phytoplankton bloom in San Francisco Bay, California, USA: implications for net ecosystem metabolism
}

\author{
Jane M. Caffrey ${ }^{1, *}$, James E. Cloern ${ }^{2}$, Christian Grenz ${ }^{3}$ \\ ${ }^{1}$ Institute of Marine Science, University of California Santa Cruz, Santa Crux, California 95064, USA \\ ${ }^{2}$ U.S. Geological Survey, 345 Middlefield Rd. MS 496, Menlo Park, California 94025, USA \\ ${ }^{3}$ Université de la Mediterranee - CNRS UMR 6535, LOB - Rue Batterie des Lions, F-13007 Marseille, France
}

\begin{abstract}
We present results of an intensive sampling program designed to measure weekly changes in ecosystem respiration (oxygen consumption in the water column and sediments) around the 1996 spring bloom in South San Francisco Bay, California, USA. Measurements were made at a shallow site $(2 \mathrm{~m}$, where mean photic depth was $60 \%$ of the water column height) and a deep site ( $15 \mathrm{~m}$, mean photic depth was only $20 \%$ of the water column). We also estimated phytoplankton primary production weekly at both sites to develop estimates of net oxygen flux as the sum of pelagic production (PP), pelagic respiration (PR) and benthic respiration (BR). Over the 14 wk period from February 5 to May 14, PP ranged from 2 to 210 , PR from 9 to 289, and $B R$ from 0.1 to $48 \mathrm{mmol} \mathrm{O}_{2} \mathrm{~m}^{-2} \mathrm{~d}^{-1}$, illustrating large variability of estuarine oxygen fluxes at the weekly time scale. Pelagic production exceeded total respiration at the shallow site, but not at the deep site, demonstrating that the shallow domains are net autotrophic but the deep domains are net heterotrophic, even during the period of the spring bloom. If we take into account the potential primary production by benthic microalgae, the estuary as a whole is net autotrophic during spring, net heterotrophic during the nonbloom seasons, and has a balanced net metabolism over a full annual period. The seasonal shift from net autotrophy to heterotrophy during the transition from spring to summer was accompanied by a large shift from dominance by pelagic respiration to dominance by benthic respiration. This suggests that changes in net ecosystem metabolism can reflect changes in the pathways of energy flow in shallow coastal ecosystems.
\end{abstract}

KEY WORDS: Estuaries Primary production - Community respiration - Ecosystem metabolism - San Francisco Bay

\section{INTRODUCTION}

What is net ecosystem metabolism (NEM) and why is it important? Originally defined as net ecosystem production by Odum (1969), NEM has been defined as the difference between gross primary production and total system respiration (Smith \& Hollibaugh 1997). It is a useful index of the trophic condition, or the relative importance of external organic matter inputs versus internal sources. If NEM is positive, ecosystems are net

·E-mail: jcaffrey@cats.ucsc.edu autotrophic and production $(\mathrm{P})$ is greater than respiration $(\mathrm{R})$, while net heterotrophic systems have greater respiration than production. The balance between net autotrophy and net heterotrophy within aquatic systems is strongly affected by the nature of exogenous inputs. Estuarine systems such as Narragansett Bay (Nixon \& Pilson 1984) and Chesapeake Bay (Kemp et al. 1997), which receive large inorganic nutrient inputs, appear to be net autotrophic while coastal systems with organic inputs such as Georgia Bight (Hopkinson 1985) and Tomales Bay (Smith \& Hollibaugh 1997) appear to be net heterotrophic. The components of NEM are dynamic, and most studies have focused 
on annual or seasonal scales of variability (Nixon \& Pilson 1984, Hopkinson 1985, Kemp et al. 1992, Smith \& Hollibaugh 1997). Previous measurements from a variety of estuaries have shown that both production and respiration often have short-term variability. Therefore, there may be imbalances between production and consumption of organic matter on shorter time scales. NEM measurements over either daily or weekly intervals were highly variable in Roskilde Fjord, Denmark (Jensen et al. 1990), Waquoit Bay, Massachusetts (D'Avanzo et al. 1996), and the MERL mesocosms (Oviatt et al. 1986).

Research from several estuarine systems suggests that physical processes are important in regulating NEM. In Tomales Bay, coastal upwelling and organic matter inputs from the watershed deliver the exogenous organic matter that sustains net heterotrophy (Smith \& Hollibaugh 1997). Both of these sources fluctuate with changes in climate. Similarly in Chesapeake Bay, physical processes exert an important control on the oxygen budget. During the summer, oxygen demand by water column and sediment respiration is greater than diffusion across the pycnocline, leading to hypoxia and sometimes anoxia (Kemp et al. 1992). A third example includes those physical processes which promote development of algal blooms-events which, by definition, are episodes of net autotrophy. We describe here results of a study designed to explore how the individual components of net ecosystem metabolism change over the course of a large bloom event in South San Francisco Bay, California, USA. The study was designed to measure the magnitude and patterns of variability in the coupled changes of primary production, pelagic respiration and benthic respiration around the spring bloom - the period of dynamic change in the strength of the autotrophic source of organic matter.

South San Francisco Bay has been a useful natural laboratory for studying ecosystem responses to phytoplankton blooms because it has a recurrent period of high phytoplankton biomass and production every spring (Cloern 1996). We exploited the predictability of the spring bloom in this lagoon-type estuary to sample before the bloom began and then intensively as phytoplankton biomass grew exponentially, peaked, and finally collapsed. Our intent was to follow closely the changes in oxygen production and consumption as the balance between phytoplankton photosynthesis and system respiration changed over the course of the spring bloom. This estuary has 2 features which make it a useful general site for studying coastal ecosystem responses to blooms. First, the spring bloom is a large biological response to changing physical dynamics: blooms begin on the (predictable) neap-tide periods of small tidal energy and weak mixing, and they are con- fined to the spring period when freshwater inflow can be high enough to establish vertical salinity stratification of the water column (Koseff et al. 1993, Cloern 1996, Lucas et al. 1998). Second, this estuary has complex bottom topography typical of coastal plain estuaries, including broad expanses of subtidal shallows that are incised by a deep central channel. The 2 bathymetric domains can have differing ecological and biogeochemical dynamics, partly because the strength of the processes of benthic-pelagic coupling (e.g. benthic nutrient regeneration, benthos grazing on phytoplankton) differs in the shallow and deep domains. One goal was to compare oxygen fluxes at shallow and deep sites.

\section{METHODS}

Study design. Specific objectives of this study were to (a) measure (or estimate) rates of phytoplankton primary production, pelagic respiration, and benthic respiration - the 3 largest components of system metabolism in this estuary; (b) characterize weekly changes in these processes and their balance, around the full course of the spring bloom; and (c) compare these changing rates of oxygen production/consumption at sites representing the 2 bathymetric domains of the estuary, i.e. a shoal site $(2 \mathrm{~m})$ on the eastern expanse of subtidal shallows (Fig. 1, S, or US Geological Survey [USGS] Stn SM46) and a deep site (15 $\mathrm{m}$ ) in the longitudinal channel (Fig. 1, C, or USGS Stn 29). These channel and shoal stations represent long-term monitoring locations by the USGS, as well as the site of previous benthic flux measurements (Caffrey et al. 1996).

Sampling included 2 measurement programs, one to document the spring bloom and associated hydrographic changes, and the second to measure rates of oxygen production/respiration as the spring bloom developed and collapsed. The 2 programs were closely synchronized, although the hydrographic and ratemeasurement samples were not always taken the same day. Hydrographic measurements included sampling along a series of fixed channel stations on 13 dates between February 1 and May 9, 1996. Vertical profiles of salinity and temperature, chlorophyll fluorescence, dissolved oxygen (DO), and irradiance (photon flux density, photosynthetically active radiation, PAR) were measured with a Sea-Bird Electronics SBE-9 CTD (conductivity-temperature-depth profiler), Sea Tech fluorometer, Sea-Bird Electronics SBE-13 oxygen electrode, and LiCor Instruments $192 \mathrm{~s}$ quantum sensor, respectively. The fluorometer and oxygen electrode were calibrated each day with discrete measurements of chlorophyll a (spectrophotometric method, using acetone extracts of sample collected onto A/E glass 


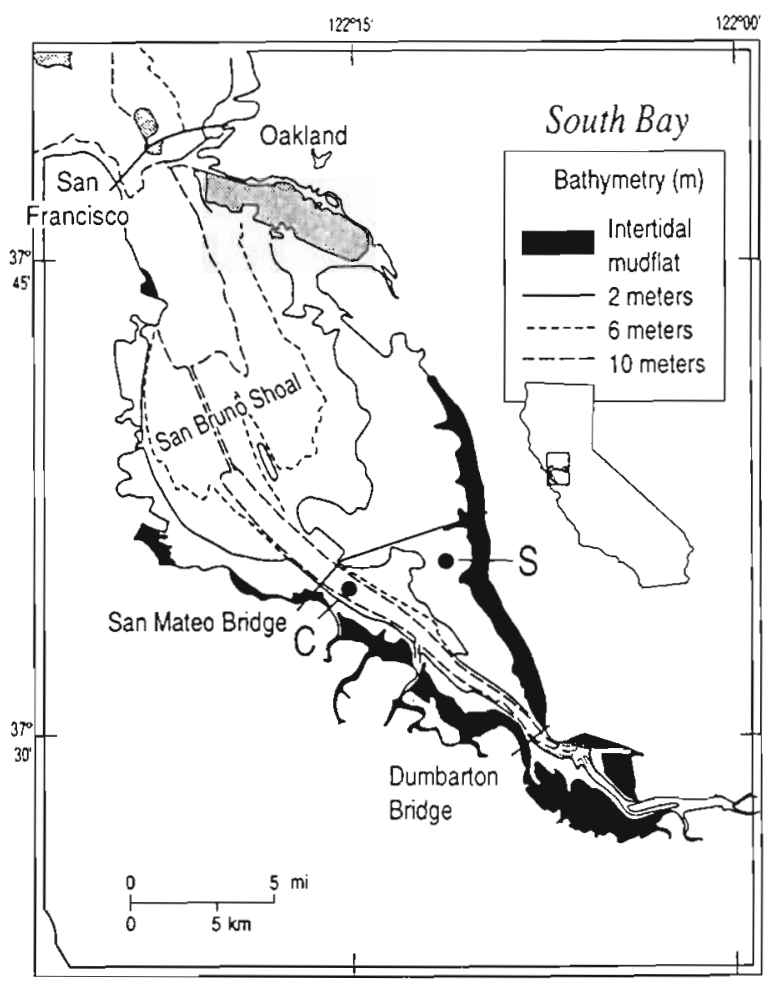

Fig. 1. Map of South San Francisco Bay, showing locations of the channel site (C) and shoal site (S) where processes of oxygen consumption and production were measured around the 1996 spring bloom

fiber filters; Lorenzen 1967, Riemann 1978) and DO (potentiometric titration method of Granéli \& Granéli 1991). Aliquots of near-surface water samples were preserved in acidified Lugol's and used for microscopic examination to determine phytoplankton species composition. Light profiles were used to calculate the attenuation coefficient $k$ as the slope of linear regression of In(irradiance) versus depth. A detailed description of methods and results is presented in the 1996 data report (Baylosis et al. 1997).

At the shoal site, near-surface and near-bottom water samples were collected with a Niskin bottle and analyzed for chlorophyll and DO concentration as above. Additional aliquots were used to measure the concentration of suspended particulate matter (SPM), by gravimetric analysis of samples collected onto Nuclepore filters. The attenuation coefficient at the shoal site was estimated from the linear relation between $k$ and SPM in San Francisco Bay $(k=0.77+$ $0.06 \times$ SPM; Cloern 1987). Surface and bottom temperature and salinity were measured with a YSI SCT (salinity-conductivity-temperature) meter. Daily surface irradiance (incident photon flux density) was measured throughout the spring with a LiCor 190 quantum sensor.
For rate measurements, water and sediment samples were collected at approximately weekly intervals between February 5 and May 14, 1996. Sampling at the shallow site was timed to coincide with high slack water, and the channel samples were collected within 1 to $2 \mathrm{~h}$ after high slack tide. Methods for each process are described below.

Pelagic respiration, PR. $\mathrm{PR}$ was measured as $\mathrm{O}_{2}$ consumption by the plankton community in dark bottles incubated for $24 \mathrm{~h}$. Water was collected in a Niskin bottle from $1 \mathrm{~m}$ below the surface and $0.5 \mathrm{~m}$ from the bottom. Twelve $300 \mathrm{ml}$ dark biological oxygen demand (BOD) bottles were filled with water from each depth and station. Six bottles were fixed immediately with Winkler reagents to give the initial $\mathrm{O}_{2}$ concentration and the remaining bottles were fixed after $24 \mathrm{~h}$ incubation at in situ temperatures. Dissolved oxygen concentrations were determined manually using starch endpoint titration with thiosulfate (Carpenter 1965). We used a trimmed mean (eliminating the highest and lowest oxygen values from each of the 6 replicates) to calculate rates. A Student's $t$-test was used to measure the significance level of differences between initial and final oxygen concentrations. In cases where the $p$ value was greater than 0.05 (initial and final oxygen concentrations were not significantly different), we concluded that the pelagic respiration rate was zero. Depth-integrated rates of pelagic respiration $\left(\mathrm{mmol} \mathrm{O}_{2}\right.$ $\mathrm{m}^{-2} \mathrm{~d}^{-1}$ ) were calculated as the mean volumetric rate of oxygen consumption in surface and bottom samples, multiplied times water column height at mean tide level $(15 \mathrm{~m}$ at the channel site and $2 \mathrm{~m}$ at the shoal site).

Benthic respiration, BR. Sediment cores $(12.1 \mathrm{~cm}$ diameter) were collected on the shoals and in the channel with a modified dart corer. The corer and attached acrylic core tube were slowly lowered into the sediments to minimize disturbance of the surface flocculent layer. Bottom water was collected at each station with a peristaltic pump from 0.5 to $1 \mathrm{~m}$ above the bottom. Triplicate cores were collected at each site and returned to the lab in dark containers filled with ambient water to minimize temperature changes. In the lab, overlying water was removed and bottom water was gently siphoned into the cores to minimize aeration of the bottom water and resuspension of the surface flocculent layer. Cores were sealed with tops equipped with magnetic stirrers and gas-tight sampling ports. The height of water overlying the sediment ranged from 21 to $31 \mathrm{~cm}$ and sediment thickness ranged from 4 to $14 \mathrm{~cm}$ at the shoal station. In the channel, the overlying water height ranged from 20 to $36 \mathrm{~cm}$ and sediment thickness ranged from 10 to $26 \mathrm{~cm}$. Cores were incubated in the dark at ambient temperatures. Four to 6 water samples $(50 \mathrm{ml})$ were removed at $2 \mathrm{~h}$ intervals 
following an initial $1 \mathrm{~h}$ incubation period. Water removed from the cores was replaced with bottom water. This resulted in a less than $1 \%$ dilution of the overlying water. Water samples for $\mathrm{O}_{2}$ analysis were collected in $7 \mathrm{ml}$ glass bottles with ground glass stoppers and Winkler reagents were added immediately. Oxygen concentrations were measured within $2 \mathrm{~h}$ of collection with an automated titration system (Metrohm $686^{\mathrm{rm}}$ ) using the potentiometric titration method of Granéli \& Granéli (1991).

Pelagic production, PP. We estimated pelagic production (PP) with the model approach of Platt et al. (1990), which calculates the depth-integrated phytoplankton photosynthesis $\mathrm{P}\left(\mathrm{mg} \mathrm{C} \mathrm{m}^{-2} \mathrm{~d}^{-1}\right)$ in a water column of height $H(\mathrm{~m})$ as:

$$
\mathrm{P}=\int_{0}^{D} \int_{0}^{H} B P_{\mathrm{m}}^{B}\left[1-\exp \left(-\alpha I_{z, t} / P_{\mathrm{m}}^{B}\right)\right] \mathrm{d} z \mathrm{~d} t
$$

This approach requires measurements of: phytoplankton biomass $B$ (mg chlorophyll $a \mathrm{~m}^{-3}$ ); the photosynthesis-irradiance parameters $P_{\mathrm{m}}^{B}$ (maximum carbon assimilation rate) and $\alpha$ (photosynthetic efficiency at low irradiance); and the irradiance $I_{z, t}$ at time $t$ and depth $z$. Diel fluctuation of surface irradiance $I_{0, t}$ is a function of photoperiod $D(\mathrm{~h})$ and total daily irradiance $I_{0}$ (mol quanta $\mathrm{m}^{-2} \mathrm{~d}^{-1}, \mathrm{PAR}$ ). The vertical distribution of light follows a uniform exponential decay:

$$
I_{z, l}=I_{0,1}[\exp (-k z)]
$$

where $k$ is the light attenuation coefficient $\left(\mathrm{m}^{-1}\right)$. We used the series approximation of Platt et al. (1990) to evaluate the integral photosynthesis. All quantities, except $P_{\mathrm{m}}^{B}$ and $\alpha$, were measured each week at the shoal and channel stations. We used fixed values $P_{\mathrm{m}}^{B}=$ $8.9 \mathrm{mg} \mathrm{C}(\mathrm{mg} \mathrm{chl} \mathrm{a})^{-1} \mathrm{~h}^{-1}$ and $\alpha=0.024$ [mg C (mg chl $a)^{-1} \mathrm{~h}^{-1}$ ] [ $\mu \mathrm{mol}$ quanta $\mathrm{m}^{-2} \mathrm{~s}^{-1} \mathrm{l}^{-1}$, which are mean values from historic measurements of phytoplankton primary production during spring months in South San Francisco Bay (Caffrey et al. 1994). We used 3 d mean values of $I_{0}$, centered around the sampling dates, to smooth the variability of production caused by the daily fluctuations in weather and a photosynthetic quotient of $1.25 \mathrm{~mol} \mathrm{O}_{2} / \mathrm{mol} \mathrm{C}$ to convert carbon production into oxygen production PP. Calculated PP is an estimate of gross photosynthesis because $P_{\mathrm{m}}^{B}$ and $\alpha$ were derived from $30 \mathrm{~min}$ incubations to measure carbon-14 uptake (Lewis \& Smith 1983).

This approach for calculating PP was based on previous investigations in South San Francisco Bay which showed that most $(93 \%)$ of the variance of phytoplankton primary production is correlated with fluctuations in chlorophyl biomass and mean irradiance in the photic zone (Cloern 1991). We estimated the potential maximum error in this approach by re-calculating PP with the minimum $\left(P_{\mathrm{m}}^{B}=6.13, \alpha=0.021\right)$ and maximum $\left(P_{\mathrm{m}}^{B}=12.45, \alpha=0.029\right)$ values of the photosynthesis-irradiance parameters measured historically during the spring months (Caffrey et al. 1994). The daily ranges between minimum and maximum $\mathrm{PP}$ are shown in Fig. 2, and these ranges define the upper limit to the error of calculated PP from fixed values of $P_{\mathrm{m}}^{B}$ and $\alpha$. Daily primary production increased by a mean increment of $29 \%$ when PP was calculated with maximum values of $P_{\mathrm{m}}^{B}$ and $\alpha$. These estimates of maximum potential error of PP are comparable to the uncertainties of the measured respiration rates (Table 1).

Table 1. South San Francisco Bay chlorophyll a, pelagic production, pelagic respiration and benthic respiration. Chlorophyll a is

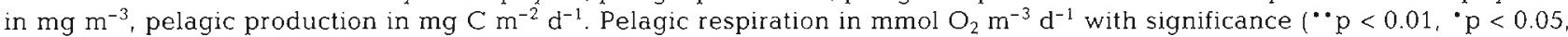
ns: non-significant) of $t$-test between initial and final dissolved oxygen concentrations. Benthic respiration in $\mathrm{mmol}_{2} \mathrm{~m}^{-2} \mathrm{~d}^{-1}$

\begin{tabular}{|c|c|c|c|c|c|c|c|c|c|c|c|c|}
\hline \multirow[t]{3}{*}{ Date } & \multirow{3}{*}{\multicolumn{2}{|c|}{$\begin{array}{l}\text { Chlorophyll a } \\
\text { Channel Shoal }\end{array}$}} & \multicolumn{2}{|c|}{ Pelagic production } & \multicolumn{4}{|c|}{ Pelagic respiration } & \multicolumn{4}{|c|}{ Benthic respiration } \\
\hline & & & \multirow[t]{2}{*}{ Channel } & \multirow[t]{2}{*}{ Shoal } & \multirow{2}{*}{\multicolumn{2}{|c|}{$\begin{array}{l}\text { Channel } \\
\text { urface Bottom }\end{array}$}} & \multicolumn{2}{|c|}{ Shoal } & \multicolumn{2}{|c|}{ Channel } & \multicolumn{2}{|c|}{ Shoal } \\
\hline & & & & & & & Surface & Bottom & Mean & $\mathrm{SD}$ & Mean & $\mathrm{SD}$ \\
\hline 5 Feb & 0.9 & 1.3 & 38 & 21 & $-4.3 \cdot$ & $-5.0 \cdot$ & $-5.5 \cdot$ & $0.0 \mathrm{~ns}$ & -3.6 & + & -0.1 & + \\
\hline 15 Feb & 2.3 & 2.1 & 303 & 137 & nd & nd & nd & nd & -11.7 & 3.7 & -0.1 & + \\
\hline $20 \mathrm{Feb}$ & 1.7 & 3.0 & 73 & 86 & $-2.5 \cdots$ & $-4.3^{\circ}$ & $-4.6^{\circ}$ & $0.0 \mathrm{~ns}$ & -15.0 & 0.1 & -7.3 & 5.0 \\
\hline 29 Feb & 2.2 & 2.8 & 251 & 117 & nd & nd & nd & nd & -24.6 & 8.6 & -19.8 & 3.7 \\
\hline $5 \mathrm{Mar}$ & 2.4 & 7.9 & 142 & 145 & nd & nd & $-6.1^{*}$ & $-10.3^{\cdots}$ & nd & & -14.0 & 1.3 \\
\hline $14 \mathrm{Mar}$ & 4.4 & 4.4 & 465 & 395 & $-7.7 \cdots$ & $-2.9 \cdots$ & $-15.5^{\prime}$ & $-15.7 \cdots$ & -19.6 & 4.8 & -21.5 & 4.1 \\
\hline $19 \mathrm{Mar}$ & 17.0 & 9.3 & 1369 & 918 & $-20.5^{\bullet}$ & $-10.6 \cdots$ & $-16.0^{*}$ & $-22.0^{\cdots}$ & -18.6 & 9.5 & -20.6 & 6.2 \\
\hline $2 \mathrm{Apr}$ & 30.8 & 39.6 & 1878 & 1220 & $-25.2 \cdot \cdot$ & $-13.3^{\cdots}$ & $-24.4^{\prime}$ & $-28.7 \cdots$ & -20.1 & 4.6 & -19.8 & 1.6 \\
\hline 9 Apr & 42.8 & 55.1 & 1767 & 1187 & $-11.1 \cdots$ & $-10.5 "$ & $-13.6 \cdot$ & $-13.7 \cdots$ & -15.5 & 7.1 & -22.0 & 0.3 \\
\hline $15 \AA \mathrm{Apr}$ & 10.7 & 32.7 & 1181 & 370 & $-10.2^{\cdots}$ & $-12.1^{\prime} \cdot$ & $-17.2 \cdot$ & $-14.3^{\prime} \cdot$ & -44.0 & 8.9 & -18.8 & 4.1 \\
\hline $24 \mathrm{Apr}$ & 2.9 & 3.5 & 356 & 349 & $-6.1 \cdot \cdot$ & $-7.0 \cdots$ & $-7.5^{\prime}$ & $-7.7 \cdots$ & -48.3 & 19.6 & -15.9 & 1.1 \\
\hline $30 \mathrm{Apr}$ & 4.0 & 3.3 & 548 & 387 & $-14.6^{\prime}$ & $-7.3^{\cdots}$ & $-6.2 \cdots$ & $-9.7 \cdot \cdot$ & -35.5 & 3.0 & -21.1 & 5.1 \\
\hline 9 May & 4.0 & 5.2 & 389 & 171 & $-3.1 \cdots$ & $-3.8 \cdots$ & $-11.5 *$ & $-11.5 \cdots$ & -28.1 & 4.9 & -16.3 & 4.1 \\
\hline $14 \mathrm{May}$ & 2.7 & 4.8 & 430 & 370 & $-6.5 \cdots$ & $-7.5 \cdots$ & $-5.5^{\prime}$ & $-6.0 \cdots$ & -36.0 & 1.8 & -14.0 & 2.7 \\
\hline
\end{tabular}
(mean and standard deviation, $\mathrm{SD} ; \mathrm{n}=3$ ). $+: \mathrm{n}=1$; nd: no data 

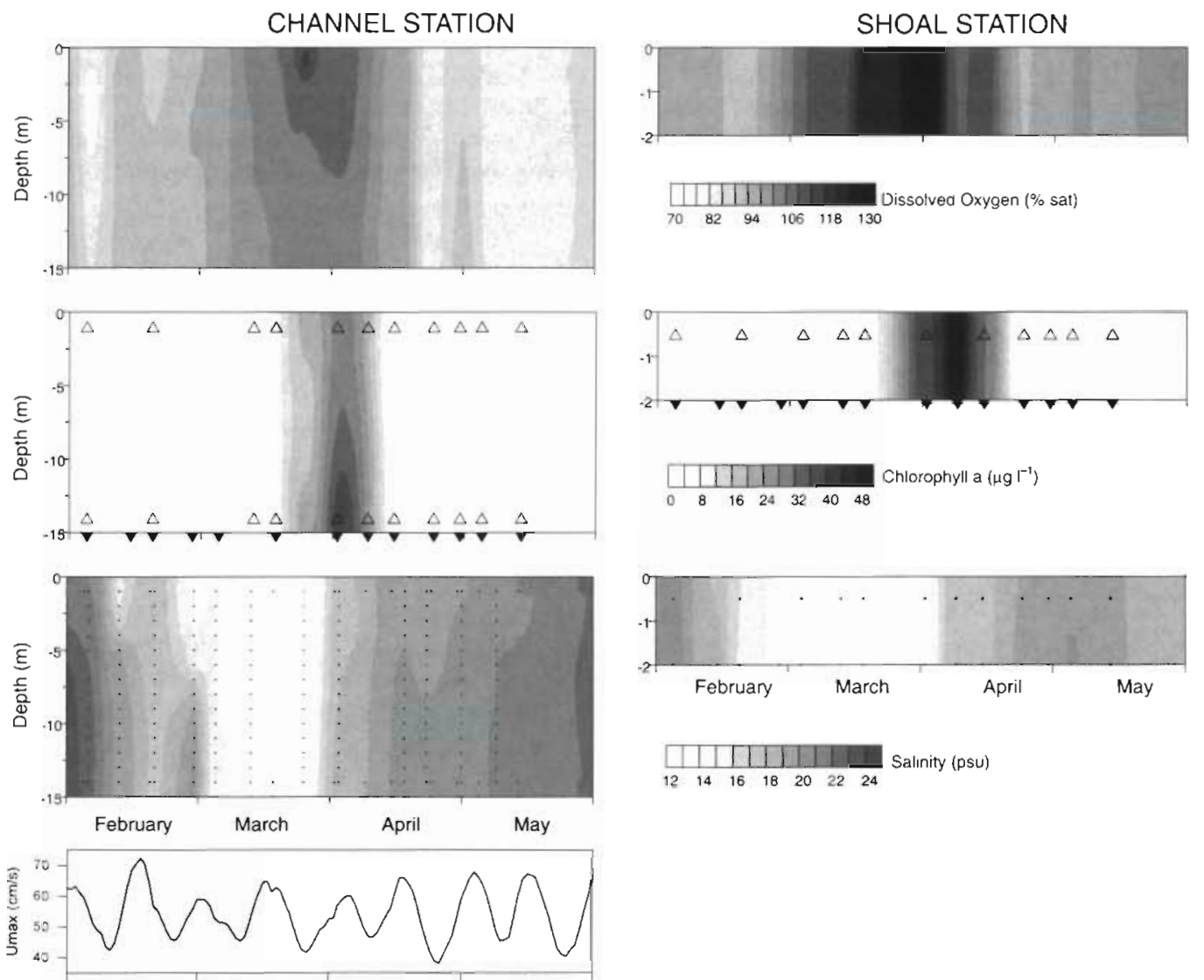

Fig. 2. Shaded contour images showing the changing vertical distributions of dissolved oxygen (upper), chlorophyll a (middle), and salinity (bottom contours) at the channel station and shoal station in South San Francisco Bay, from February (pre-bloom) through May (post-bloom). Contour shadings were drawn from interpolated (by kriging) grids produced from the discrete measurements indicated with solid dots. $(\Delta)$ Times and locations where water samples were collected for measurement of pelagic respiration. ( $\boldsymbol{\nabla})$ Times when cores were taken for measurement of benthic respiration. Left bottom panel shows the time series of tidal current speed, as predicted daily maximum current speed $\left(U_{\text {max }}\right)$ in mid-South San Francisco Bay (J. W. Gartner pers. comm.)

\section{RESULTS}

\section{The 1996 spring bloom}

The spring bloom has been followed in South San Francisco Bay each year since 1978, and it is a strong biological response to changing physical dynamics of the estuary (Cloern 1996). In the deep channel, the establishment of persistent salinity stratification appears to be a key to triggering blooms (Koseff et al. 1993), and persistent stratification develops following periods of high river flow and weak tidal mixing (Lucas et al. 1998). The hydrographic measurements in 1996 were consistent with this connection between bloom development, river flow, and tidal mixing in the channel. The spring of 1996 was one of above-average precipitation and river flow, and we observed large salinity fluctuations at the channel and shoal sites. In January 1996, salinity at the channel station was 26 psu; but by the beginning of this study on February
1, surface salinity was depressed to 20.7 psu (Fig. 2) by the runoff produced during the first winter storms. By mid-February, surface salinity fell to 15.3 ; by late March the surface salinity at the channel site decreased to the annual minimum of 12.7 psu. Salinity began to increase in April as the period of storms and high flow ended. Although horizontal salinity gradients develop across the estuary, there was strong coherence in the weekly changes in salinity between the shoal and channel sites (Fig. 2).

We measured large changes in the intensity of salinity stratification in the channel, with large vertical salinity differences (up to $5 \mathrm{psu}$ ) on the neap tides of February 13, March 1, and March 26 (Fig. 2). Salinity stratification broke down on the intervening springtide periods of strong currents and mixing. Each episode of stratification coincided with an increase in chlorophyll biomass in the surface layer, but the biomass increases were small until mid-March. Then, we observed exponential biomass growth, with chloro- 
phyll concentrations increasing from pre-bloom levels of 1 to 3 to peaks $>40 \mathrm{mg} \mathrm{m}{ }^{-3}$. Biomass increased rapidly over the shoals at the same time, and reached maximum chlorophyll concentration of $55 \mathrm{mg} \mathrm{m}^{-3}$ on April 9 (Fig. 2). The spring bloom collapsed quickly, first as accumulation of chlorophyll in the deep water of the channel, and then as a rapid decrease of biomass in the channel and shallows.

Collapse of the bloom in early April was probably a result of nutrient limitation. Before the spring bloom began, concentrations of dissolved inorganic nitrogen (DIN) were $>50 \mu \mathrm{M}$ at the channel site and $>70 \mu \mathrm{M}$ at the shoal site (S. W. Hager unpubl.). On April 9, DIN concentrations were only $0.46 \mu \mathrm{M}$ at the channel site and $0.13 \mu \mathrm{M}$ at the shoal site. Similar depletion of dissolved silicate occurred during the bloom, with concentrations changing from pre-bloom peaks of $150 \mu \mathrm{M}$ to minimum concentrations of $1.1 \mu \mathrm{M}$ on April 9 (S. W. Hager unpubl.). The rapid silicate depletion reflected the dominance of diatoms (Coscinodiscus radiatus, Thalassionema sp., Thalassiosira spp., Cyclotella spp.) during the spring bloom, although cryptophytes were also very abundant.

The weekly changes in primary production were reflected in the changing oxygen concentrations at both sites (Fig. 2). In the channel, DO concentrations were always undersaturated with respect to atmospheric oxygen in February and May (pre- and postbloom). However, DO concentrations began to increase in early March, even before chlorophyll biomass began to reach high levels. This shows that primary production began to increase around March $1_{i}$ DO concentration continued to increase, especially in the surface layer, and peaked around the neap-tide period of weak mixing and strong stratification in late March. This was the only period of DO supersaturation in the channel. As the bloom collapsed and primary production decreased, so did the DO concentration in the channel. Oxy gen concentrations at the shallow site were almost always $\geq$ saturation (Fig. 2), and they were supersaturated during the end of the exponential growth of chlorophyll biomass (all DO measurements were made in the morning). These observations suggest large spatial variability in the balance between system production and respiration: in the channel, respiration typically exceeded production; in the shallow region production exceeded respiration during the spring bloom.

\section{Oxygen production and consumption}

During the course of this study there were large fluctuations in the calculated rate of pelagic (primary) production by phytoplankton (Fig. 3). For example, at the channel site PP was $<10 \mathrm{mmol} \mathrm{O}_{2} \mathrm{~m}^{-2}$ $\mathrm{d}^{-1}$ in early February, $>200 \mathrm{mmol} \mathrm{O}_{2} \mathrm{~m}^{-2}$ $\mathrm{d}^{-1}$ in late March, and then declined to about $40 \mathrm{mmol} \mathrm{O}_{2} \mathrm{~m}^{-2} \mathrm{~d}^{-1}$ after the bloom cycle ended. This variability was associated with changes in chlorophyll biomass (ranging from 0.9 to $42.8 \mathrm{mg} \mathrm{m}^{-3}$ ), daily surface irradiance (ranging from about 10 to 50 mol quanta $\mathrm{m}^{-2} \mathrm{~d}^{-1}$ ), and turbidity ( $k$ ranged from 0.7 to $3.6 \mathrm{~m}^{-1}$ ). Peaks in estimated PP coincided with the peaks in
Fig. 3. Weekly fluctuations of pelagic (primaryl production (PP), depth-integrated pelagic respiration (PR), benthic respiration (BR), and the sum of these processes as net oxygen flux (NOF), from measurements made at the deep channel station and lateral shoal station. All panels have units $\mathrm{mmol} \mathrm{O}_{2} \mathrm{~m}^{-2}$ $\mathrm{d}^{-1}$. Asterisks denote times when PR was not measured; these rates are estimates from interpolation. Vertical lines in the top panels show the calculated $\mathrm{PP}$ with minimum and maximum values of the photosynthesis-irradiance parameters $P_{m}^{B}$ and $\alpha$ 
DO (Fig. 2), and both quantities showed a large pulse increase in the production of oxygen (and phytoplankton biomass) that persisted for about a month and peaked in late March. In terms of production, the bloom response was larger at the channel site than the shoal site because the mean turbidity $(k)$ was 3 times larger over the shoals than in the channel. However, the photic zone occupied a larger fraction $(60 \%)$ of the water-column in the shoals compared to the channel (20\%).

Pelagic respiration measurements ranged between 0 and $28.7 \mathrm{mmol} \mathrm{O}_{2} \mathrm{~m}^{-3} \mathrm{~d}^{-1}$ in the spring of 1996 (Table 1). Surface and bottom rates were generally similar except during late March and early April, when stratification was prolonged. At this time, respiration rates in the surface waters of the channel were greater than in bottom waters. In contrast, rates in the shoal bottom water were higher than in surface water. Compared to the productivity estimates and chlorophyll a concentrations, PR measurements declined very slowly following the bloom. The pattern of fluctuation in depth-integrated PR (Fig. 3) was similar to the pattern of PP fluctuation, suggesting that the pelagic consumption of oxygen was stimulated immediately after primary production began to increase during the bloom. PR rates were similar between channel and shoal stations on a volumetric basis. However, there were large differences between the channel and shoal site in the rate of depth-integrated pelagic respiration. The largest oxygen flux measured in this study was the integrated pelagic oxygen consumption in the channel during the bloom peak (Fig. 3).

Rates of sediment oxygen consumption ranged from 3.6 to $48 \mathrm{mmol} \mathrm{O}_{2} \mathrm{~m}^{-2} \mathrm{~d}^{-1}$ in the channel and from 0.1 to $22 \mathrm{mmol} \mathrm{O}_{2} \mathrm{~m}^{-2} \mathrm{~d}^{-1}$ at the shoal station (Table 1). Respiration rates were comparable at both stations until early April. About 2 wk following the peak in chlorophyll a concentrations, BR rates in the channel more than doubled. In contrast, rates in the shoal were constant throughout the sampling period. The fluctuations of $\mathrm{BR}$ therefore showed no clear response to the bloom at the shoal site, and the stimulation of BR in the channel that was delayed, by about $2 \mathrm{wk}$, from the occurrence of high chlorophyll in the deep waters of the channel (Fig. 2).

These weekly changes in the production and consumption of oxygen suggest the possibility of large fluctuations in net ecosystem metabolism. Although we did not measure all components of system metabolism, the processes included here are the 3 most important sources and sinks of organic matter in South San Francisco Bay (Jassby et al. 1993). Therefore, we can use the net oxygen flux (NOF $=\mathrm{PP}-\mathrm{PR}-\mathrm{BR}$ ) measured in our study as an index to describe the patterns of weekly variability in system metabolism. Weekly
Table 2. Mean oxygen fluxes $\left(\mathrm{mmol} \mathrm{O}_{2} \mathrm{~m}^{-2} \mathrm{~d}^{-1}\right)$ at the channel and shoal site from measurements made between February 5 and May 14, 1996, representing the period of the spring bloom. Values in parentheses are coefficients of variation (standard deviation/mean). Values in italics are calculated pelagic production and net oxygen flux (NOF) using the photosynthetic quotient $\mathrm{PQ}=1$ instead of $\mathrm{PQ}=1.25 . \mathrm{NOF}=21.7$ $-6.42 \times$ Depth; Baywide mean $\approx-6.1 \mathrm{mmol} \mathrm{O}_{2} \mathrm{~m}^{-2} \mathrm{~d}^{-1}$

\begin{tabular}{|lcc|}
\hline Process & $\begin{array}{c}\text { Channel } \\
\text { (Depth }=15 \mathrm{~m} \text { ) }\end{array}$ & $\begin{array}{c}\text { Shoal } \\
\text { (Depth }=2 \mathrm{~m} \text { ) }\end{array}$ \\
\hline Pelagic production & $78.6(0.97)$ & $48.4(0.95)$ \\
& 62.9 & 38.7 \\
Pelagic respiration & $-128.8(0.58)$ & $-23.9(0.57)$ \\
Benthic respiration & $-24.4(0.53)$ & $-15.6(0.50)$ \\
Net oxygen flux & -74.6 & 8.9 \\
& -90.3 & -0.8 \\
\hline
\end{tabular}

fluctuations of NOF are shown in Fig. 3, and 2 patterns are evident. First, the magnitude of NOF was very different for the 2 spatial domains: the NOF was small or positive in the shallow (mostly photic) domain, and almost always large and negative in the deep (mostly aphotic) channel. The dominant component of oxygen flux in the channel was the large loss to pelagic respiration. Second, there was a clear response to the spring bloom in both spatial domains: NOF was positive ( + +50 to $\left.+100 \mathrm{mmol} \mathrm{O}_{2} \mathrm{~m}^{-2} \mathrm{~d}^{-1}\right)$ over the shoal site, and NOF increased (from about -100 to $0 \mathrm{mmol} \mathrm{O}_{2} \mathrm{~m}^{-2} \mathrm{~d}^{-1}$ ) in the channel during the late-March period of highest primary production.

The integrated system metabolism over the spring period can be indexed as the time-averaged NOF. We calculated the mean PP, PR, and BR at each site by trapezoidal integration of the weekly measurements shown in Fig. 3. These calculations show that during spring, the integrated NOF at the shoal site was positive (mean $+8.9 \mathrm{mmol} \mathrm{O}_{2} \mathrm{~m}^{-2} \mathrm{~d}^{-1}$ ), but the NOF was large and negative (mean $-74.6 \mathrm{mmol} \mathrm{O}_{2} \mathrm{~m}^{-2} \mathrm{~d}^{-1}$ ) at the channel site (Table 2). These estimates confirm the presence of large spatial variability in the balance between system production and respiration. Much of this variability results from the spatial gradients in the ratio of photic depth to water depth.

\section{DISCUSSION}

\section{Changing oxygen fluxes around the spring bloom}

The focus of this study was the process of oxygen consumption as a measure of the changing metabolic activity of the pelagic and benthic communities of South San Francisco Bay. Oxygen-consuming metabolism requires a source(s) of useable organic matter, and 
in this estuary the largest source of organic matter is primary production by phytoplankton (Jassby et al. 1993). Therefore, we asked here how fluctuations in the consumption of organic matter, expressed as oxygen uptake, are coupled to the dynamic changes in phytoplankton production. The spring bloom of 1996 was a month-long event of high pelagic production that was coherent in the channel and shoal regions, providing an ideal natural event for addressing this question. Our measurements showed 2 results that may be general features of estuarine metabolism.

First, the fluxes of oxygen in the water column and sediments showed large variability at the weekly time scale. During this 14 wk study, PP ranged from 2 to $210 \mathrm{mmol} \mathrm{O} \mathrm{m}^{-2} \mathrm{~d}^{-1}$, PR from 8.8 to $289 \mathrm{mmol} \mathrm{O}_{2} \mathrm{~m}^{-2}$ $\mathrm{d}^{-1}$, and $\mathrm{BR}$ from 0.1 to $48 \mathrm{mmol} \mathrm{O}_{2} \mathrm{~m}^{-2} \mathrm{~d}^{-1}$. Therefore, rates of oxygen production and consumption in estuaries can vary by more than an order of magnitude within one season. Here, the rate of oxygen production was more variable than the rates of consumption: the coefficient of variation of PP was about 1 (Table 2), while the coefficients of variation of $P R$ and $B R$ were about half this magnitude. The smaller relative variance suggests that the respiration response to a signal of enhanced production is damped, perhaps reflecting the fact that community respiration is fueled by sources in addition to phytoplankton production. For example, PR proceeded at a rate of about $5 \mathrm{mmol} \mathrm{O}_{2}$ $\mathrm{m}^{-2} \mathrm{~d}^{-1}$ in early February (Table 1 ), before the bloom began.

Strong covariation in the rates of production and pelagic respiration suggests that the increased production of organic matter during the spring bloom stimulated community metabolism in the water column, and that this stimulation occurred with only a short time lag. This fast response of the pelagic biota is well described from work in other systems. In the Menai Strait (North Wales, UK), the major respiration response by bacterioplankton depended on the phytoplankton species responsible for the bloom (Blight et al. 1995). PR increased during the exponential growth phase of a Rhizosolenia bloom, but lagged 1 to 2 wk after the peak in a Phaeocystis bloom (Blight et al. 1995). North Atlantic bloom experiments also showed short lags between production of organic matter and consumption by heterotrophic grazers (Bender et al. 1992). In contrast, plankton respiration in Chesapeake Bay exhibited a very tight coupling with no lags between production and respiration, suggesting the importance of labile sources of organic matter (Sampou \& Kemp 1994). In South San Francisco Bay, the spring bloom is a period of greatly enhanced bacterial production (Hollibaugh \& Wong 1996), as well as microzooplankton abundance, and recruitment of copepods and benthic invertebrates such as spionid polychaetes (Ambler et al. 1985). These heterotrophs all contribute to the consumption of organic matter. However, most studies suggest that picoplankton or bacterioplankton are responsible for most of the PR (Williams 1981, Hopkinson et al. 1989, Griffith et al. 1990. Sampou \& Kemp 1994, Blight et al. 1995). Chlorophyll a and water column respiration were significantly correlated in our study (PR $=6.41+0.27 \mathrm{chl} a_{1} \mathrm{r}^{2}=0.47, \mathrm{p}<0.01$ ), and previous measurements in San Francisco Bay also demonstrated a significant relationship between chlorophyll $a$ and respiration, particularly at chlorophyll a concentrations above $10 \mathrm{mg} \mathrm{m}^{-3}$ (Rudek \& Cloern 1996). This suggests that phytoplankton may be responsible for a significant fraction of the pelagic respiration.

Benthic respiration rates at both sites were comparable to previous measurements in South San Francisco Bay (Caffrey et al. 1996). Work in other coastal ecosystems has shown a response of enhanced benthic metabolism during periods of high primary production (Graf 1992, Banta et al. 1995). We were surprised that BR remained stable at the shallow site of South San Francisco Bay (Fig. 3). However BR was stimulated at the deep site, within a few weeks after the peaks in PP and chlorophyll. This pattern has been observed before: rates of ammonium mineralization in shoal sediments were fairly constant during the spring while rates in channel sediments increased by an order of magnitude following the spring bloom (Caffrey 1995). In addition, the biomass of benthic macrofauna increased in the channel following the spring bloom from $12.0 \pm 7.2$ (mean $\pm \mathrm{SD}$ ) to $25.0 \pm 17.4 \mathrm{~g}$ dry $w \mathrm{t} \mathrm{m}^{-2}$, but remained fairly constant in the shoals, from $5.5 \pm 1.7 \mathrm{~g}$ dry wt $\mathrm{m}^{-2}$ prebloom to $3.5 \pm 2.1 \mathrm{~g}$ dry wt $\mathrm{m}^{-2}$ post bloom (O. Mace pers. comm.). The benthic macrofaunal community included several species of bivalve mollusks (Potamocorbula amurensis, Mya arenaria, Musculista senhousia), crustaceans (Cumella vulgaris and the amphipods Ampelisca abdita and Corophium $\mathrm{sp}$.), which began to increase in population abundance and total biomass in mid-April, coincident with the time of enhanced BR in the channel (Fig. 3).

Mean values of NOF (Table 2) illustrate the second general outcome of this study: the balance between production and respiration can differ markedly between the shallow and deep domains of estuaries. The reason for this is apparent from Fig. 3, which shows that $\mathrm{PP}$ and $\mathrm{BR}$ were of comparable magnitude at the channel and shoal sites, but that integral PR was nearly 8 times greater at the channel site than the shoal site. This difference simply reflects the larger pelagic biomass contained in the $15 \mathrm{~m}$ water column of the channel compared to the $2 \mathrm{~m}$ water column over the shoal site.

As a result of the large PR in the channel, the calculated NOF was negative there (Table 2). However, the 
NOF at the shoal site was positive. Therefore, the shallow regions of the estuary are a net source of oxygen and organic matter during the spring, while the deep regions are a net sink. In the terminology of Smith \& Hollibaugh (1997), the shallows act as a 'donor system' while the deep channel is a 'recipient system'. This differential balance between production and respiration at the 2 sites suggests that some of the organic matter produced over the shoals during the spring bloom is transported to the channel, where it is consumed by pelagic biota or deposited onto the deep sediments and metabolized by the benthos. Similar results have been observed in other systems (Graf 1992, Noji et al. 1993). This interpretation is consistent with other measurements, including the stimulation of BR in the channel but not the shoal site (Fig. 3), accumulation of chlorophyll in bottom waters of the channel as the spring bloom collapsed (Fig. 2), and parallel accumulations of chlorophyll within the surficial sediments of the channel, but not the shoals (authors' unpubl. data).

Although these observations are all consistent with the concept of shallow regions as donor systems, we must remember the large uncertainties of each component of system metabolism (Kemp et al. 1997). These uncertainties arise from measurement errors as well as error in the assumptions embedded in the calculation of net metabolism. For example, if we convert carbon production into oxygen production with a photosynthetic quotient $(P Q)$ of 1 , instead of 1.25 , then the NOF changes, and even the shallow regions appear to be net heterotrophic (Table 2).

\section{Implications for net ecosystem metabolism}

Although the measurements in our study do not give a complete picture of ecosystem metabolism, they strongly suggest that the shallow regions of South San Francisco Bay are net autotrophic $(\mathrm{P}>\mathrm{R})$ in spring, while the deep regions are net heterotrophic $(P<R)$. What about the P-R balance for the estuary as a whole? We can use results from the channel and shoal sites to provide a first-order answer to this question by assuming an inverse (linear) relation between NOF and water depth (Fig. 4a), and then applying this function to estimate NOF across the South San Francisco Bay hypsograph (Fig. 4b). The result shows a small positive NOF in regions where water depth at mean tide $<3.4 \mathrm{~m}$, which is about $60 \%$ of the estuary surface area. At depths $>3.4 \mathrm{~m}, \mathrm{NOF}$ is negative. The mean NOF integrated across the hypsograph is $-6.1 \mathrm{mmol} \mathrm{O}_{2}$ $\mathrm{m}^{-2} \mathrm{~d}^{-1}$, showing that the sum of pelagic and benthic respiration exceeds pelagic production in the spring, when we take into account the bathymetry of the entire estuary. The calculated oxygen deficit is equiva-
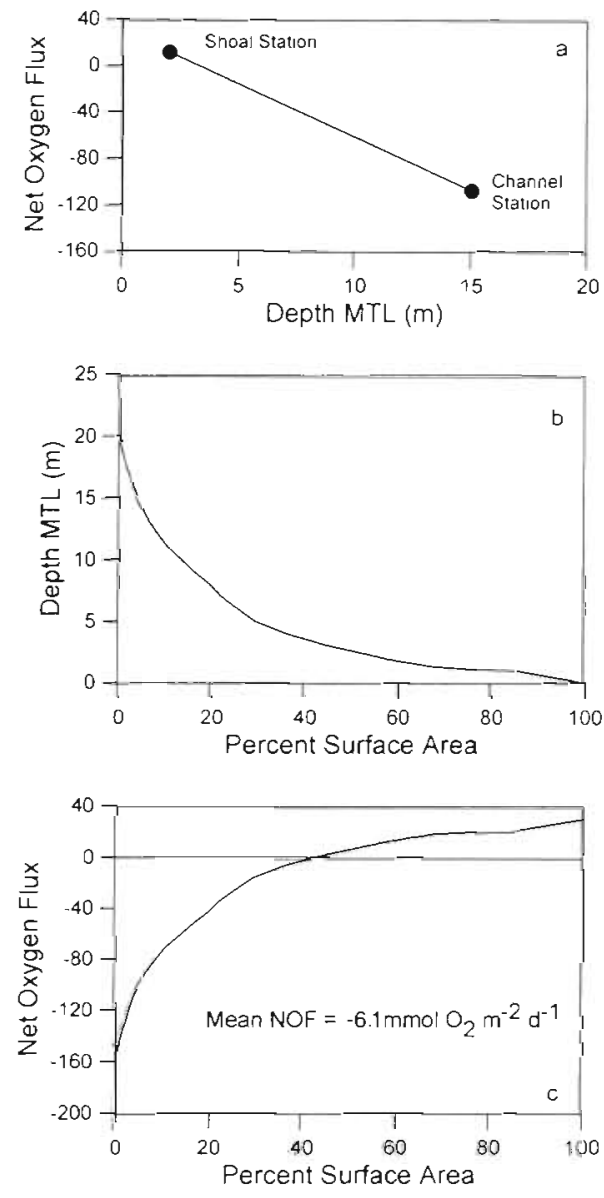

Fig. 4. Procedure for estimating the baywide balance between pelagic production, pelagic respiration and benthic respiration (= net oxygen flux, NOF). (a) Linear relation between NOF and water column height based on the mean NOF at the $15 \mathrm{~m}$ channel site and $2 \mathrm{~m}$ shoal site for the period of the 1996 spring bloom (Table 2). (b) The South San Francisco Bay hypsograph (from Jassby et al. 1993). (c) Spatial variability of NOF across the mean bathymetry of the estuary, by applying the linear relation in (a) across the hypsograph (b). The NOF in spring is positive in the shallow regions, negative in the deep channels, and averages $-6.1 \mathrm{mmol} \mathrm{O}_{2} \mathrm{~m}^{-2} \mathrm{~d}^{-1}$ across the hypsograph

lent to an organic carbon deficit of about $6 \mathrm{mmol} \mathrm{C} \mathrm{m}^{-2}$ $\mathrm{d}^{-1}$ (assuming a respiratory quotient of 1 )

Jassby et al. (1993) assessed the relative importance of all potential sources of organic carbon to South San Francisco Bay, and they concluded that contributions from vascular plants are negligible and that external loadings (from runoff, point sources, marsh export) are

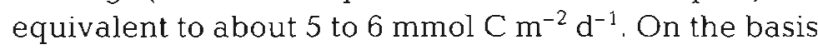
of intertidal habitat area of South San Francisco Bay and a median primary productivity of $25 \mathrm{mmol} \mathrm{C} \mathrm{\textrm {m } ^ { - 2 }}$ $\mathrm{d}^{-1}$ by benthic microalgae from published studies of 28 coastal systems, Jassby et al. (1993) concluded that benthic production (BP) could contribute a baywide 
mean of $15 \mathrm{mmol} \mathrm{C} \mathrm{m} \mathrm{m}^{-2} \mathrm{~d}^{-1}$. Therefore, our best current estimate is that South San Francisco Bay is net autotrophic during the spring season of high phytoplankton production, and the net ecosystem metabo-

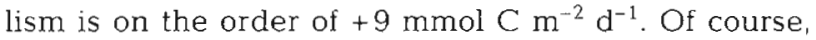
this estimate is highly uncertain because it is based on the assumption of a linear relation between NOF and water depth, it does not consider the possibility of longitudinal gradients in the balance between $\mathrm{P}$ and $\mathrm{R}$ (Kemp et al. 1997), and it does not include direct measurements of photosynthesis by the benthic microalgae.

In other estuaries, measurements of benthic oxygen fluxes in light and dark chambers indicate that shallow subtidal sediments can be a significant oxygen source. Estimates from the Neuse River estuary (North Carolina, USA) suggest that sediments in water depths $\leq 2 \mathrm{~m}$ are net autotrophic in the mesohaline region (Rizzo et al. 1992). Even at relatively deep water depths, significant benthic production can occur (Sundbäck et al. 1991). In contrast, BP was positive only during winter and early spring in sandy shallow sediments ( $1 \mathrm{~m}$ water depth) in Chesapeake Bay (Reay et al. 1995). Given the shallow photic depths in South San Francisco Bay, benthic microalgae would make the greatest contribution to net metabolism in the intertidal and shallow subtidal domains.

Another factor which may affect the estimate of NEM is sulfate reduction and oxidation of sulfides. In estuarine sediments, the use of benthic oxygen fluxes as a substitute for benthic respiration has been questioned (Kemp et al. 1997). Kemp et al. (1997) suggest that oxidation of sulfides is a significant component of $\mathrm{BR}_{i}$ in fact, half of the measured BR may be due to sulfide oxidation. They estimated BR for Chesapeake Bay based on measured sulfate reduction rates and oxygen utilization (respiration). In their sensitivity analysis, using benthic oxygen flux alone led to a more positive estimate of NEM, than when sulfate reduction was used to estimate BR. Although sulfate reduction has not been measured directly in San Francisco Bay, Hammond et al. (1985) estimated that sulfate reduction in South San Francisco Bay was about $30 \%$ of total $\mathrm{CO}_{2}$ flux. Based on these estimates, if all sulfide produced was oxidized, this process would represent about half of sediment oxygen flux. If we apply the Kemp et al. (1997) correction to the BR values in Table 2 and assume that sulfate reduction is the same in channel and shoals, the new $\mathrm{BR}$ values would be 17.9 and $13.5 \mathrm{mmol} \mathrm{O}_{2} \mathrm{~m}^{-2} \mathrm{~d}^{-1}$ for channel and shoal respectively and new NOF would be -68.1 and $+11.0 \mathrm{mmol} \mathrm{O}_{2} \mathrm{~m}^{-2} \mathrm{~d}^{-1}$ (channel and shoal, respectively), which is probably not significantly different than the uncorrected values.

The estimate of positive NEM is not valid for other seasons, but we can use the few measurements of pelagic respiration and benthic respiration made previously to estimate mean respiration rates for the summer-autumn-winter period of low phytoplankton biomass and production. Results are summarized in Table 3, which compares mean depth-integrated PR at the channel and shoal sites (assuming equal rates of

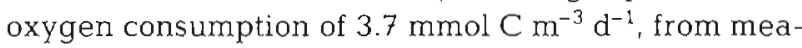
surements of Rudek \& Cloern 1996), and mean BR from the measurements made by Caffrey et al. (1996) between 1991 and 1993. Pelagic production was estimated from measurements of chlorophyll $a$ and $k$ at the channel station on 13 dates between April 30, 1993 and January 19, 1994 (the nonbloom period when PR was measured by Rudek \& Cloern 1996). Again, if the benthic respiration values are corrected for oxidation of sulfides, corrected benthic respiration values are much lower, 34.0 and $33.9 \mathrm{mmol} \mathrm{O}_{2} \mathrm{~m}^{-2} \mathrm{~d}^{-1}$ for channel and shoal respectively, while the net oxygen fluxes are less negative -48.6 and $-0.3 \mathrm{mmol} \mathrm{O}_{2} \mathrm{~m}^{-2} \mathrm{~d}^{-1}$ channel and shoal, respectively.

Comparison of results in Tables $2 \& 3$ shows how the key processes of oxygen flux change from the springbloom period to the subsequent periods of persistent

Table 3. Mean oxygen fluxes $\left(\mathrm{mmol} \mathrm{O}_{2} \mathrm{~m}^{-2} \mathrm{~d}^{-1}\right)$ at channel and shoal sites in South San Francisco Bay, from measurements during nonbloom periods (May through January) of 1991-1993. Values in italics are calculated pelagic production and net oxygen flux using the photosynthetic quotient $P Q=1$ instead of $P Q=1.25 . \mathrm{NOF}=-15.2-3.73 \times$ Depth; Baywide mean $\approx-31.4 \mathrm{mmol} \mathrm{O}_{2} \mathrm{~m}^{-2} \mathrm{~d}^{-1}$

\begin{tabular}{|c|c|c|}
\hline Process & $\begin{array}{c}\text { Channel } \\
\text { (Depth }=15 \mathrm{~m})\end{array}$ & $\begin{array}{c}\text { Shoal } \\
(\text { Depth }=2 \mathrm{~m})\end{array}$ \\
\hline Pelagic production ${ }^{a}$ & $\begin{array}{l}41 \\
32.8\end{array}$ & $\begin{array}{l}41 \\
32.8\end{array}$ \\
\hline Pelagic respiration ${ }^{b}$ & -55.6 & -7.4 \\
\hline Benthic re & -56.6 & \\
\hline Net oxygen flux & $\begin{array}{l}-71.2 \\
-79.4\end{array}$ & $\begin{array}{l}-22.7 \\
-30.9\end{array}$ \\
\hline \multicolumn{3}{|c|}{$\begin{array}{l}\text { Mean of calculated daily phytoplankton photosynthesis } \\
\text { from } 13 \text { measurements of chlorophyll } a, k \text {, and surface } \\
\text { irradiance at the channel station between April } 30,1993 \\
\text { and January } 19,1994 \text {. Assumes that gross photosynthesis } \\
\text { is equivalent at channel and shallow sites (Cole \& Cloern } \\
\text { 1984) }\end{array}$} \\
\hline \multicolumn{3}{|c|}{$\begin{array}{l}\text { 'Mean of measured rates of oxygen consumption in sur- } \\
\text { face waters collected at } 2 \text { channel stations in June, } \\
\text { August, October, and December } 1993 \text { (Rudek \& Cloern } \\
\text { 1996). Assumes that the mean respiration rate is equal to } \\
\text { the mean }\left(3.7 \mathrm{mmol} \mathrm{O}_{2} \mathrm{~m}^{-3} \mathrm{~d}^{-1}\right) \text { at the channel and shal- } \\
\text { low sites }\end{array}$} \\
\hline \multicolumn{3}{|c|}{$\begin{array}{l}\text { "Mean rates of sediment oxygen consumption from mea- } \\
\text { surements made at the channel and shoal site during the } \\
\text { nonbloom periods (May through January) of 1991-1993 } \\
\text { (Caffrey et al. 1996) }\end{array}$} \\
\hline
\end{tabular}


low phytoplankton biomass. Mean pelagic production is smaller in summer-autumn-winter than in spring; pelagic respiration is also (substantially) smaller, but benthic respiration is 2 to 4 times higher during the nonbloom periods compared to spring. This shift from pelagic to benthic metabolism is partly a result of the annual growth cycle of the benthic macrofauna, which reproduce after the spring bloom, grow during summer, and progressively contribute more to system metabolism in summer-autumn (Thompson 1998). The net result of these seasonal changes is a reduced system metabolism in deep regions and a shift from net autotrophy to net heterotrophy in the shallow regions after the spring bloom ends (Table 3 ).

We used the same approach as above to estimate NOF across the hypsograph, and estimated a mean daily net oxygen flux in South San Francisco Bay of about $-31 \mathrm{mmol} \mathrm{O}_{2} \mathrm{~m}^{-2} \mathrm{~d}^{-1}$ for the seasons outside the spring bloom period. If this baywide NOF applies for $265 \mathrm{~d} \mathrm{yr}^{-1}$ and the net oxygen flux of $-6 \mathrm{mmol} \mathrm{O}_{2} \mathrm{~m}^{-2}$ $\mathrm{d}^{-1}$ applies for $100 \mathrm{~d}$ each year around the spring bloom, then the annual NOF is about $-24 \mathrm{mmol} \mathrm{O}_{2} \mathrm{~m}^{-2}$ $\mathrm{d}^{-1}$. This baywide mean rate of oxygen consumption is similar to, and almost balanced by, the Jassby et al. (1993) estimate of benthic production, which is equivalent to $+19 \mathrm{mmol} \mathrm{O} \mathrm{O}^{-2} \mathrm{~d}^{-1}$ (assuming $\mathrm{PQ}=1.25$ ) Therefore, the available measurements and estimates of oxygen fluxes at deep and shallow sites, when extrapolated across the entire estuary, suggest that the South San Francisco Bay ecosystem is: net autotrophic during the spring months; net heterotrophic during the other seasons. It appears that the Bay ecosystem has an annual metabolism in which benthic and pelagic production are nearly balanced by benthic and pelagic respiration. This result must be considered as an hypothesis until the 2 key processes, photosynthesis by the benthic microalgae and sulfate reduction, are measured seasonally in this estuary. If this hypothesis is correct, then the annual NEM shows South San Francisco Bay to be an example of a coastal ecoystem in which exogenous sources of organic matter play a minor role in fueling heterotrophic production.

Acknowledgements. Support for this project was provided by the USGS Toxic Substances Hydrology Program, USGS San Francisco Bay Ecosystem Program, Institute of Marine Srience CALPIRG-Shell settlement fund, and the French CNRS. C. Grenz received sabbatical support from NATO. We thank Brian Cole, Scott Conard, Jody Edmunds, Jim Kuwabara, Jelriza Baylosis, Francis Parchaso, Byron Richards for their assistance in the field and laboratory, Richard Dufford for enumeration/identification of phytoplankton, Oscar Mace for measuring macrofaunal biomass, and Steve Hager for sharing nutrient data. We also thank 4 anonymous reviewers for their suggestions

\section{LITERATURE CITED}

Ambler JW, Cloern JE, Hutchinson A (1985) Seasonal cycles of zooplankton from San Francisco Bay. Hydrobiologia 129:177-197

Banta GT, Giblin AE, Hobbie JE, Tucker J (1995) Benthic respiration and nitrogen release in Buzzards Bay, Mass. J Mar Res 53:107-135

Baylosis JI, Edmunds JL, Cole BE, Cloern JE (1997) Studies of the San Francisco Bay, California, estuarine ecosystem. Pilot Regional Monitonng Program Results, 1996: US Geological Survey Open-File Report 97-598

Bender M, Ducklow H, Marra J, Martin J (1992) The carbon balance during the 1989 spring bloom in the North Atlantic Ocean, $47^{\circ} \mathrm{N}, 20^{\circ} \mathrm{W}$. Deep-Sea Res 39:1707-1725

Blight SP, Bentley TL, Lefevre D, Robinson C, Rodrigues R, Rowland J, Williams PJleB (1995) Phasing of autotrophic and heterotrophic plankton metabolism in a temperate coastal ecosystem. Mar Ecol Prog Ser 128:61-75

Caffrey JM (1995) Spatial and seasonal patterns in sediment ammonium concentrations and regeneration rates in San Francisco Bay, CA. Estuaries 18:219-233

Caffrey JM, Cole BE, Cloern JE, Rudek J, Tyler AC, Jassby AD (1994) Studies of the plankton and its environment in the San Francisco Bay Estuary, California. Regional Monitoring Results, 1993: U.S. Geological Survey Open-File Report $94-82$

Caffrey JM, Hammond DE, Kuwabara JS, Miller LG, Twilley RR (1996) Benthic processes in South San Francisco Bay: the role of organic inputs and bioturbation. In: Hollibaugh JT (ed) San Francisco Bay: the ecosystem. AAAS Pacific Division, San Francisco, CA, p 425-444

Carpenter JH (1965) The Chesapeake Bay Institute technique for the Winkler dissolved oxygen method. Limnol Oceanogr 10:141-143

Cloern JE (1987) Turbidity as a control on phytoplankton biomass and productivity in estuaries. Cont Shelf Res 7: $1367-1381$

Cloern JE (1991) Annual variations in river flow and primary production in the South San Francisco Bay Estuary. In Elliott M, Ducrotoy D (eds) Estuaries and coasts: spatial and temporal intercomparisons. Olsen and Olsen, Fredensborg, p 91-96

Cloern JE (1996) Phytoplankton bloom dynamics in coastal ecosystems: A. review with some general lessons from sustained investigation of San Francisco Bay, California. Rev Geophysics 34(2):127-168

Cole BE, Cloern JE (1984) Significance of biomass and light availability to phytoplankton productivity in San Francisco Bay. Mar Ecol Prog Ser 15:15-24

D'Avanzo C, Kremer JN, Wainright SC (1996) Ecosystem production and respiration in response to eutrophication in shallow temperate estuaries. Mar Ecol Prog Ser 141 263-274

Graf $G$ (1992) Benthic-pelagic coupling: a benthic view. Oceanogr Mar Biol Annu Rev 30:149-190

Granéli W, Granéli E (1991) Automatic potentiometric determination of dissolved oxygen. Mar Biol 108:341-348

Griffith PC, Douglas DJ, Wainright SC (1990) Metabolic activity of size-fractionated microbial plankton in estuarine, nearshore and continental shelf waters of Georgia. Mar Ecol Prog Ser 59:263-270

Hammond DE, Fuller C, Harmon D, Hartman B, Korosec $A$, Miller LG, Rea R, Warren S, Berelson W, Hager SW (1985) Benthic fluxes in San Francisco Bay. Hydrobiologia 129 $69-90$

Hollibaugh JT, Wong PS (1996) Distribution and activity of 
bacterioplankton in San Francisco Bay. In: Hollibaugh JT (ed) San Francisco Bay: the ecosystem. AAAS Pacific Division, San Francisco, CA, p 263-288

Hopkinson CS Jr (1985) Shallow-water benthic and pelagic metabolism: evidence of heterotrophy in the nearshore Georgia Bight. Mar Biol 94:127-142

Hopkinson CS Jr, Sherr B, Wiebe WJ (1989) Size fractionated metabolism of coastal microbial plankton. Mar Ecol Prog Ser 51:155-166

Jassby AD, Cloern JE, Powell TM (1993) Organic carbon sources and sinks in San Francisco Bay: variability induced by river flow. Mar Ecol Prog Ser 95:39-54

Jensen LM, Sand-Jensen K, Marcher S, Hansen M (1990) Plankton community respiration along a nutrient gradient in a shallow Danish estuary. Mar Ecol Prog Ser 61:75-85

Kemp WM, Sampou PA, Garber J, Tuttle J, Boynton WR (1992) Seasonal depletion of oxygen from bottom waters of Chesapeake Bay: roles of benthic and planktonic respiration and physical exchange processes. Mar Ecol Prog Ser $85: 137-152$

Kemp WM, Smith EM, Marvin-DiPasquale M. Boynton WR (1997) Organic carbon balance and net ecosystem metabolism in Chesapeake Bay. Mar Ecol Prog Ser 150: $229-248$

Koseff JR, Holen JK, Monismith SG, Cloern JE (1993) Effects of vertical mixing and benthic grazing on phytoplankton populations in shallow, turbid estuaries. $J$ Mar Res 51 $843-868$

Lewis MR, Smith JC (1983) A small volume, short-incubationtime method for measurement of photosynthesis as a function of incident irradiance. Mar Ecol Prog Ser 13:99-102

Lorenzen CJ (1967) Determination of chlorophyll and pheopigments: spectrophotometric equations. Limnol Oceanogr $12: 343-346$

Lucas L, Cloern JE, Koseff JR, Monismith SG, Thompson JK (1998) Does the Sverdrup Critical Depth Model explain bloom dynamics in estuaries? J Mar Res 56:375-415

Nixon SW, Pilson MEQ (1984) Estuarine total system metabolism and organic exchange calculated from nutrient ratios: an example from Narragansett Bay. In: Kennedy VS (ed) The estuary as a filter. Academic Press, Orlando, FL, p 261-290

Noji TT, Noji CI, Barthel KG (1993) Pelagic-benthic coupling during the onset of winter in a northern Norwegian fjord.

Editorial responsibility: Otto Kinne (Editor),

Oldendorf/Luhe, Germany
Carbon flow and fate of suspended particulate matter. Mar Ecol Prog Ser 93:89-99

Odum EP (1969) The strategy of ecosystem development Science 164:262-270

Oviatt CA, Keller AA, Sampou PA, Beatty LL (1986) Patterns of productivity during eutrophication: a mesocosm experiment. Mar Ecol Prog Ser 28:69-80

Platt T, Sathyendranath S, Ravindran P (1990) Primary production by phytoplankton: andytic solutions for daily rates per unit of water surface. Proc R Soc Lond Ser B 241 : $101-111$

Reay WG, Gallagher DL, Simmons GM Jr (1995) Sedimentwater column oxygen and nutrient fluxes in nearshore environments of the lower Delmarva Peninsula, USA. Mar Ecol Prog Ser 118:215-227

Riemann B (1978) Carotenoid interference in spectrophotometric determination of chlorophyll degradation products from natural populations of phytoplankton. Limnol Oceanogr 23:1059-1066

Rizzo WM, Lackey GJ, Christian RR (1992) Significance of euphotic, subtidal sediments to oxygen and nutrient cycling in a temperate estuary. Mar Ecol Prog Ser 86: $51-61$

Rudek J, Cloern JE (1996) Planktonic respiration rates in San Francisco Bay. In: Hollibaugh JT (ed) San Francisco Bay: the ecosystem. AAAS Pacific Division, San Francisco, CA, p 289-304

Sampou P, Kemp WM (1994) Factors regulating plankton community respiration in Chesapeake Bay. Mar Ecol Prog Ser 110:249-258

Smith SV, Hollibaugh JT (1997) Annual cycle and interannual variability of ecosystem metabolism in a temperate climate embayment. Ecol Monogr 67:509-533

Sundbäck K, Enoksson V. Granéli W. Pettersson K (1991) Influence of sublittoral microphytobenthos on the oxygen and nutrient flux between sediment and water: a laboratory continuous-flow study, Mar Ecol Prog Ser 74:263-279

Thompson JK (1998) The effect of infaunal bivalve grazing on phytoplankton bloom development in south San Francisco Bay based on in situ grazing rate estimates. PhD dissertation, Stanford University

Williams PJleB (1981) Microbial contribution to overall marine plankton metabolism: direct measurements of respiration. Oceanol Acta 4:359-364

Submitted: February 20, 1998; Accepted: July 17, 1998

Proofs received from author(s): September 21, 1998 